\title{
Defying Putin: Leaders of the Opposition Movement Against Russian Authoritarianism
}

Megan Tingley

Since being named acting president of Russia in 1999, Vladimir Putin has gone from a little-known ex-KGB agent to one of the most powerful men in the world. Handpicked by his ailing predecessor, Boris Yeltsin, Putin came to power following a decade of economic turmoil and political instability. His decisiveness, especially in regard to civic uprisings in Chechnya, garnered early support among the Russian people. ${ }^{1}$ In fact, Putin's approval ratings remained high even as his actions became increasingly authoritarian. ${ }^{2}$ Given Russia's position of power and its recent invasion of Crimea, there is reasonable concern among the international community over Putin's ongoing obstructions to democracy both within and outside the country's borders. Over the past few years, however, opposition groups have emerged with hopes of limiting Putin's power. While widespread reform has yet to occur, movements to mobilize the Russian public are beginning to take place.

Putin's means of maintaining high public support are concerning, especially from a Western standpoint. During the beginning of his presidency, for example, Putin publicly denounced the former oligarchs of the 1990s by warning that they would no longer have political power over the country, only to later promote his own generation of oligarchs, with whom he exchanged political support for economic privilege. ${ }^{3}$

Although the extent of his corruption may not be evident to the Russian masses, Putin's popularity still hasn't dipped in the midst of other, more publicized conflicts. The decision to annex Crimea, for example, was overwhelmingly supported by the Russian public. ${ }^{4}$ Additionally, there was no significant 
change in Putin's approval ratings during the recent economic crisis. Today this number remains in the mid-80s, an exceptionally high level for a state leader. ${ }^{5}$ In comparison, Boris Yeltsin's approval rating was estimated to be as low as 2 percent at the end of his presidency. ${ }^{6}$ Putin's approval rating, however, may not provide a completely accurate representation of the public's opinion. Although it's widely agreed that Putin is generally well liked, critics have noted that these polls don't measure the depth of a person's support, which may not be as great as these numbers suggest. Similarly, others have pointed out that Putin's rating may be reflection of fear. In an authoritarian state, people are more likely to say they approve of a leader if they perceive a potential harm in voicing their true opinions. ${ }^{7}$

Putin has also been able to effectively consolidate political power. During his three terms as president and one as prime minister - Russian law prohibits the president from serving three consecutive terms - Putin has limited the civil liberties of his people in order to advance his own political agenda. While serving as prime minister, Putin ensured he was still the primary power in Russia. Prior to the elections, he paved the way for his protégé Dmitry Medvedev to assume power, who instantly assumed a submissive role to Putin upon his presidency. ${ }^{8}$ At the end of his term, Medvedev decided not to run for reelection, allowing Putin to regain his position as president. By controlling the media, imprisoning opponents and benefitting from suspicious electoral results, Putin has positioned himself and the United Russia party to maintain political dominance for years to come. ${ }^{9}$ It follows that those attempting to depose Putin must overcome myriad obstacles.

Despite clear difficulties, pro-democracy leaders are confident that change is possible: Mikhail Khodorkovsky has been one of the most vocal supporters of political reform since the beginning of Putin's presidency. Perhaps the most famous individual in Russia besides the president himself, Khodorkovsky seems an unlikely candidate to lead the shift towards a liberal democracy. Once the richest man in the country, Khodorkovsky made his fortune as an oligarch in the 1990s by taking advantage of the country's post-communist instability.

In order to make his oil business, Yukos, more appealing to Western investors, Khodorkovsky began to advocate for a more transparent Russia in the late-1990s and early-2000s. In 2001 he founded Open Russia, an organization dedicated to promoting Russian democracy. He has since admitted that these efforts were initially motivated by financial self-interest, claiming, "Our position was that, in order for our capitalization to grow, we needed a more transparent political system". ${ }^{10}$

Khodorkovsky's efforts to liberalize Russian politics didn't bode well with Putin. Early in his presidency, Putin made it clear that he wouldn't tolerate any political involvement from the oligarchs of the 1990s. But, in spite of this warning, Khodorkovsky continued to openly criticize the president. ${ }^{11}$ In response, Putin had Khodorkovsky arrested on charges of fraud and tax evasion in 2003. The businessman was subsequently 
sentenced to nine years in prison. In 2007, more charges - this time for embezzlement and money laundering - were brought down and Khodorkovsky was sentenced to an additional seven years. It's widely agreed that both arrests were politically motivated. ${ }^{12}$

In the midst of rumors of a third case being held against the former oligarch, Putin made the surprising decision to pardon Khodorkovsky in December 2013. Many believe this was an attempt to improve Russia's reputation in the West after accusations of human rights violations prior to the 2014 Winter Olympics in Sochi. ${ }^{13}$ When asked about Khodorkovsky's release, however, Putin claimed his decision was made on humanitarian grounds. ${ }^{14}$

As part of his release, Khodorkovsky had to submit to certain conditions: he was not to attempt to regain any of the Yukos shares he lost to the state, and he was to immediately leave Russia for a life in exile. After an initial stay in Germany, Khodorkovsky settled in Switzerland, where he remains today. Finally, Khodorkovsky was not to become involved in Russian politics. Whether or not he has followed this third provision depends on one's definition of "political involvement."

Khodorkovsky maintains he has no desire to become directly involved in Russian politics, and that he only wishes to promote civil liberties. In Sept. 2014, however, he said he would lead Russia "if it appeared necessary to overcome the crisis and to carry out constitutional reform, the essence of which would be to redistribute presidential powers in favor of the judiciary, parliament and civil society." 15
The primary means by which Khodorkovsky hopes to achieve this goal is through the recently revitalized Open Russia organization. While Khodorkovsky originally founded Open Russia to advance his financial interests, the organization is now devoted to promoting "independent media, political education, and support for political prisoners." 16 In doing so, he will help reform Russia so that it may become more Western. Khodorkovsky estimates that only about 12 percent of Russians currently favor a European-style government. ${ }^{17}$ Despite this low percentage, Khodorkovsky believes that the level of support in Moscow may be as high as 30 percent, leading him to believe that democratic values can spread on a larger scale. "Since Russian politics is made in big cities," he argues, "these people could have a big impact."18

Of course, moving the public to support Khodorkovsky's efforts will be no easy task. Putin still has the support of the general populace and exercises control over Russian media outlets. This latter point has recently been of great annoyance to Khodorkovsky and his team: Open Russia's broadcasts are frequently disconnected, making it more difficult to expand their audience. ${ }^{19}$

Additionally, Khodorkovsky's life in exile raises concern about his ability to lead an effective campaign. Making the matter worse, the majority of Open Russia's management team lives outside the country. ${ }^{20}$ Khodorkovsky's biggest issue, however, may be with image maintenance. Many Russians still view him as part of the group of oligarchs who stole from the country. To this end, Khodorkovsky has argued that he already 
served his time for such offenses. "I've done my time. And other people's time," he stated. "And, to those who say I should've done more time, you try doing ten years." 21

Another opposition leader, Alexei Navalny, has recently emerged as the new face of the movement. The 38 year-old lawyer gained prominence in 2008 through LiveJournal, his blog devoted to exposing state corruption. As a minority stockholder in Russia's statecontrolled oil companies and banks, Navalny began asking top executives uncomfortable questions about incomplete reports of the state finances. ${ }^{22}$

Since then, Navalny has successfully organized several large-scale protests, most notably during the 2011 parliamentary and the 2012 presidential elections. During the former cycle, he denounced United Russia as "the party of crooks and thieves", a sound bite that has become a rallying cry for the opposition. ${ }^{23}$ After the Dec. 2011 elections, Navalny organized several protests in Moscow in response to accusations of ballot stuffing, which were the largest anti-government protests since the fall of the Soviet Union. He was arrested shortly thereafter for resisting the police and spent 15 days in prison.

He, however, wasn't discouraged. Later that month, Navalny spoke at another protest, in which the number of attendees was estimated to be at least 28,000, urging the public to recognize their potential to defy Putin in the upcoming presidential elections. ${ }^{24}$ During the speech he cried, "Who's the power here?" and the crowd responded, "We are!"25 Although Putin eventually won, Navalny was still able to mount an impressive opposition: In
March 2012, he organized an anti-Putin protest, and an estimated 14,000 to 20,000 people participated.

As was the case with Khodorkovsky, the response from the Kremlin has been swift and brutal: Navalny was arrested for 15 days following a protest in May 2012. In Jul. 2013, he was again arrested and sentenced to five years in prison for embezzlement. He was released a day after out of government officials fear of backlash. ${ }^{26}$

Nevertheless, in the face of these legal threats, Navalny made the bold decision to run in the Sept. 2013 Moscow mayoral race. He finished in second place, with 27 percent of the vote. This was especially remarkable because his campaign relied mostly on social media. ${ }^{27}$ Navalny even expressed doubt over the results, believing his percentage of the votes to be higher. ${ }^{28}$

In his most recent conflict with the Kremlin, Navalny, along with his brother Oleg, was again subject to trumped-up charges of embezzlement in Feb. 2014. Persecutors have accused the brothers of stealing about $\$ 500,000$ from the French cosmetics company Yves Rocher between 2008 and 2012 in a case that's widely seen as punishment for Navalny's ongoing criticisms of Putin. ${ }^{29}$ Navalny was subsequently placed under house arrest and was forbidden to use the Internet. ${ }^{30}$ When the case went to trial in December, Navalny was given a suspended prison sentence of 42 months. Meanwhile, his brother was given the same sentence, except his was to be served immediately. Since the court's decision, Navalny has defied the terms of his house arrest multiple times, including to join protests of his trial's decision and also to 
buy milk at the grocery store. ${ }^{31,32}$ Navalny hasn't been subtle about these acts either: $\mathrm{He}$ posted pictures of being out in public and of cutting off his ankle bracelet to his blog. ${ }^{33}$

On Feb. 17, an appeals court upheld both Navalny and his brother's sentences. Only a few days later, Navalny was given a 15-day jail sentence for handing out pamphlets for an anti-Putin rally that was to take place in March in light of Russia's recent economic troubles. The rally, however, evolved to serve as a memorial for slain opposition leader Boris Nemtsov, who was murdered on Feb. 27, just blocks from the Kremlin. Putin's critics claim that Nemtsov's death was a deliberate act by the Kremlin meant to instill fear in Putin's opponents. 34 Navalny admits that Nemtsov's death is a huge blow to the opposition movement. "We didn't realize how important he was until we lost him," Navalny said. "It's obvious that the only plan the Kremlin has for us is destruction. The mood has gotten worse. That was the goal. To intimidate us and spread more fear." 35
While there are definite similarities between Khodorkovsky and Nav alny, the two men face different obstacles in advancing their efforts. If
Throughout his presidency, Putin has consistently hindered democracy in favor of more authoritarian practices, and there is no reason to suggest he will limit such actions to the internal affairs of the country. As Putin has already demonstrated, Russia has the ability to extend its reach beyond its borders. the former hopes to initiate a democratic transition while in exile, he will need to be able to effectively communicate with Russian citizens. During his 10 years in prison, the former oligarch missed a substantial transition in the primary method of communication: social media. He has admittedly had difficulty adjusting, which may hurt his efforts in mobilizing the younger generation. ${ }^{36}$ On the other hand, social media has proved to be one of Navalny's greatest strengths. Through his charisma and wit, Navalny has been able to use his blog and Twitter to engage in fiery attacks on Putin. Though Navalny has also faced similar difficulties with the state-controlled media, the real cause for concern lies elsewhere. Many are wary of his background in

nationalistic ideologies. ${ }^{37}$

A self-proclaimed "nationalist democrat", Navalny has a long association with groups perceived to be xenophobic. He has participated in the Russian March, an annual event organizing the various Russian 
nationalist groups where some crowd member have made Nazi salutes, and in 2011, Navalny spoke on behalf of Stop Feeding the Caucasus, a movement intended to end federal subsidies to governments in Chechnya and the North Caucasus regions. ${ }^{38}$ In doing so, he made several comments that have been criticized within the opposition movement for being ethnocentric. Likewise, in voicing his support for the 2008 war in Georgia, Navalny used racial slurs when calling for all Georgians to leave Russia. ${ }^{39} \mathrm{He}$ was also criticized in 2011 for comments against ethnic Chechens following a racial altercation in the small Russian town of Pugachev. ${ }^{40}$ Such actions contradict the notion of a liberal Russian state, and in order to organize an effective pro-democracy movement, Navalny will have to be careful not to alienate those with similar goals.

It's important to note that Navalny has claimed that his nationalist views have been embellished by the Kremlin, and that discussing issues important to ethnic Russians related to inter-ethnic conflict does not entail extreme nationalism. ${ }^{41}$ Nonetheless, many of Navalny's critics are justified in their concerns related to his nationalistic actions. Democracy advocates should be wary of Navalny's often-overlooked nationalist background. Such tendencies contradict the notion of a liberal democracy, which may ultimately undermine an eventual democratic transition. Navalny, therefore, may not be a desirable replacement for Putin should he successfully overthrow the president. Due to his extensive history of nationalist involvement, Navalny has given little reason to believe that he would serve as a greater proponent for Russian democracy than Putin himself.

Despite Khodorkovsky and Navalny's efforts, widespread political opposition against Putin has yet to be achieved. At this point there appears to be little threat to Putin's power, and there are no signs of a democratic transition occurring in the near future. This is of great concern to the international community, as Putin has recently shown an increasingly authoritarian presence on the world stage. Given Russia's power as a permanent member of the U.N. Security Council, other countries have sufficient reason to question Putin's intentions. Throughout his presidency, Putin has consistently hindered democracy in favor of more authoritarian practices, and there is no reason to suggest he will limit such actions to the internal affairs of the country. As Putin has already demonstrated, Russia has the ability to extend its reach beyond its borders.

Thus far, Putin has been successful in maintaining support among the vast majority of the Russian public, and United Russia has shown that it will do whatever necessary to maintain political power. Additionally, in light of the fear instilled by Boris Nemtsov's murder, the opposition movement against Putin has faced a major setback. "If before we were demanding honest elections, now we're just demanding to have elections at all," Navalny said. "Our politics has been reduced to the most primitive form possible. What can we do apart from protests and handing out leaflets?" 42 With the opposition movement losing momentum and the Kremlin continuing to consolidate power, Putin seems poised to 
retain his position as the primary authority in

${ }^{1}$ Denis Volkov, "Putin's Ratings: Anomaly or Trend?," Institute of Modern Russia, December 23, 2014, Internet (accessed February 2, 2015).

${ }^{2}$ Mark Ardomanis, "Vladimir Putin's Approval Rate Is Still Near An All-Time High," Forbes, October 6, 2014, Internet (accessed February 2, 2015).

${ }^{3}$ Andrew S. Weiss, "Russia's Oligarchy, Alive and Well," The New York Times, December 30, 2013, Internet (accessed February 2, 2015).

4 Anna Arutunyan, “Voices: Why Putin's popularity defies logic," USA Today, December 3, 2014, Internet (accessed February 2, 2015).

${ }^{5}$ Laura Mills and Lynn Berry, "Poll: 81 percent back Putin even as ruble falls," The Associated Press, December 18, 2014, Internet (accessed February 2, 2015).

6 Mark Tran, "A bold buffoon," The Guardian, April 23, 2007, Internet (accessed February 11, 2015).

7 Saeed Ahmed, "Vladimir Putin's approval rating? Now at a whopping 86\%," CNN, February 26, 2015, Internet (accessed February 26, 2015).

8 Anne Applebaum, "Is Dmitry Medvedev ready to stand up to Vladimir Putin?," The Telegraph, April 14, 2011, Internet (accessed March 17, 2015).

${ }^{9}$ Melik Kaylan, "How Putin Invented the New Authoritarianism," Forbes, January 28, 2014, Internet (accessed February 2, 2015).

10 Julia loffe, "Remote Control: Can an exiled oligarch persuade Russia that Putin must
Russian politics for years to come.

go?," The New Yorker, January 12, 2015, Internet (accessed February 3, 2015).

11 Paul Sonne, Anton Troianovski, and Bertrand Benoit, "Russia Frees Mikhail Khodorkovsky," The Wall Street Journal, December 20, 2013, Internet (accessed February 3, 2015).

12 Jeanne Whalen, "Putin Foe Mikhail Khodorkovsky Aims to Remake Russia," The Wall Street Journal, October 3, 2014, Internet (accessed February 3, 2015).

13 Michael Ray, "Mikhail Khodorkovsky," Encyclopedia Britannica, July 28, 2014, Internet (accessed February 3, 2015).

14 Roland Oliphant, "Mikhail Khodorkovsky freed after Vladimir Putin signs pardon," The Telegraph, December 20, 2013, Internet (accessed February 11, 2015).

15 Agence France-Presse, "Mikhail Khodorkovsky breaks political silence, saying he would lead Russia," The Guardian, September 20, 2014, Internet (accessed February 3, 2015).

16 Jeanne Whalen, "Putin Foe Mikhail Khodorkovsky Aims to Remake Russia."

17 Ibid.

18 lbid.

19 Julia loffe, "Remote Control: Can an exiled oligarch persuade Russia that Putin must go?" 20 lbid.

21 Ibid.

22 "Profile: Russian opposition leader Alexei Navalny," BBC News, December 30, 2014, Internet (accessed February 11, 2015).

23 Tom Parfitt, "Russian opposition activist Alexei Navalny fined for suggesting United Russia member was thief," The Telegraph, 
June 5, 2012, Internet (accessed February 11, 2015).

24 "Moscow protest: thousands rally against Vladimir Putin," BBC News, December 24, 2011, Internet (accessed February 11, 2015).

25 "Moscow protest: thousands rally against Vladimir Putin," Ibid.

${ }^{26}$ Miriam Elder, "Russian opposition leader Alexei Navalny released from custody," The Guardian, July 19, 2013, Internet (accessed February 11, 2015).

27 "Profile: Russian opposition activist Alexei Navalny," Ibid.

28 Alec Luhn, "Alexei Navalny demands recount in Moscow mayoral election," The Guardian, September 9, 2013, Internet (accessed February 11, 2015).

${ }^{29}$ Andrew Roth, "Court Orders House Arrest, and No Internet, for Fierce Critic of Putin," The New York Times, February 28, 2014, Internet (accessed March 17, 2015).

30 Agence France-Press, "Alexei Navalny placed under house arrest in Russia," The Guardian, February 28, 2014, Internet (accessed February 11, 2015).

${ }^{31}$ Anna Nemtsova, "Alexei Navalny detained after breaking house arrest to join rally in Moscow," The Guardian, December 30, 2014, Internet (accessed February 11, 2015).

32 Associated Press, "Anti-corruption campaigner Alexei Navalny defies house arrest to buy milk," The Guardian, January 6, 2015, Internet (accessed February 11, 2015). 33 Laura Smith-Spark, Matthew Chance and Alla Eshchenko, "Kremlin critique Alexey Navalny arrested hours after sentencing," CNN, January 2, 2015, Internet (accessed February 13, 2015).
${ }^{34}$ Shaun Walker, "Alexei Navalny: Russian opposition is not deterred by Boris Nemtsov murder," The Guardian, March 6, 2015, Internet (accessed March 17, 2015).

${ }^{35}$ Max Seddon, "Russia's Main Opposition Leader Still Thinks He Can Change Russia," BuzzFeed News World, March 12, 2015, Internet (accessed March 17, 2015).

${ }^{36}$ Julia loffe, "Remote Control: Can an exiled oligarch persuade Russia that Putin must go?" 37 Peter Popham, "Alexei Navalny: The greatest threat to Putin," The Independent, January 2, 2015, Internet (accessed February 11, 2015).

${ }^{38}$ Tom Parfitt, "Alexei Navalny: Russia's new rebel who has Vladimir Putin in his sights," The Guardian, January 15, 2012, Internet (accessed February 26, 2015).

${ }^{39}$ Robert Coalson, "Is Aleksei Navalny a Liberal or a Nationalist?" The Atlantic, July 29, 2013, Internet (accessed February 26, 2015). ${ }^{40}$ Mark Adomanis, "Did Russian Opposition Leader Alexei Navalny Just Endorse a Race Riot?" Forbes, July 15, 2013, Internet (accessed February 26, 2015).

${ }^{41}$ Robert Coalson, "Is Aleksei Navalny a Liberal or a Nationalist?"

42 Shaun Walker, "Alexei Navalny: Russian opposition is not deterred by Boris Nemtsov murder." 